\title{
WGDB: Wood Gene Database with search interface
}

\author{
Neha Goyal \& H.S. Ginwal*
}

Division of Genetics and Tree Propagation, Forest Research Institute, Dehradun, U.K, INDIA; H.S. Ginwal - Email: ginwalhs@icfre.org; *Corresponding author

Received January 07, 2014; Accepted January 17, 2014; Published January 29, 2014

\begin{abstract}
:
Wood quality can be defined in terms of particular end use with the involvement of several traits. Over the last fifteen years researchers have assessed the wood quality traits in forest trees. The wood quality was categorized as: cell wall biochemical traits, fibre properties include the microfibril angle, density and stiffness in loblolly pine [1]. The user friendly and an open-access database has been developed named Wood Gene Database (WGDB) for describing the wood genes along the information of protein and published research articles. It contains 720 wood genes from species namely Pinus, Deodar, fast growing trees namely Poplar, Eucalyptus. WGDB designed to encompass the majority of publicly accessible genes codes for cellulose, hemicellulose and lignin in tree species which are responsive to wood formation and quality. It is an interactive platform for collecting, managing and searching the specific wood genes; it also enables the data mining relate to the genomic information specifically in Arabidopsis thaliana, Populus trichocarpa, Eucalyptus grandis, Pinus taeda, Pinus radiata, Cedrus deodara, Cedrus atlantica. For user convenience, this database is cross linked with public databases namely NCBI, EMBL \& Dendrome with the search engine Google for making it more informative and provides bioinformatics tools named BLAST,COBALT.
\end{abstract}

Availability: The database is freely available on www.wgdb.in

Keywords: Wood, Cellulose, Pinus, Cedrus, Poplar, Eucalyptus.

\section{Background:}

Wood is single greatest material aid and comfort in every century. Molecular knowledge of wood has an important role for development of improved wood. Furthermore improvement in quality of wood, researcher should have information of its genomic background. Although there exists many number of databases on wood which are the resources of morphology and its anatomical characters, the database related to genomic information of wood trait is unavailable till date Table 1 (see supplementary material). Database of Japanese wood contains the data regarding the wood specimen surface views, optical microscopic images with the limited number of data. Database of wood specimens contain the information related to specimen no., family name, species name, original name, wood specimen number, herbarium number, geographical location. Indian Wood Insect Database contains ISSN 0973-2063 (online) 0973-8894 (print)

Bioinformation 10(1): 039-042 (2014) the information related to diversity of indigenous and exotic wood insects/pests in India. It includes the details of various wood yielding trees, taxonomic status, properties and durability. WGDB comprises the gene specific data in different species and clones with their position on chromosomes, specific length in sequenced genomes. It provides the PMID (PubMed Database ID) of literature where the specific genes information has been published.

\section{Architecture of Database:}

WGDB has been designed on the three layer structure i.e. Data layer, middle layer and presentation layer. Data layer is consisted through SQL server, whereas middle layer comprises in visual studio. HTML and CSS have been implemented to make online presentation layer of the database to make database user friendly (Figure 1). 


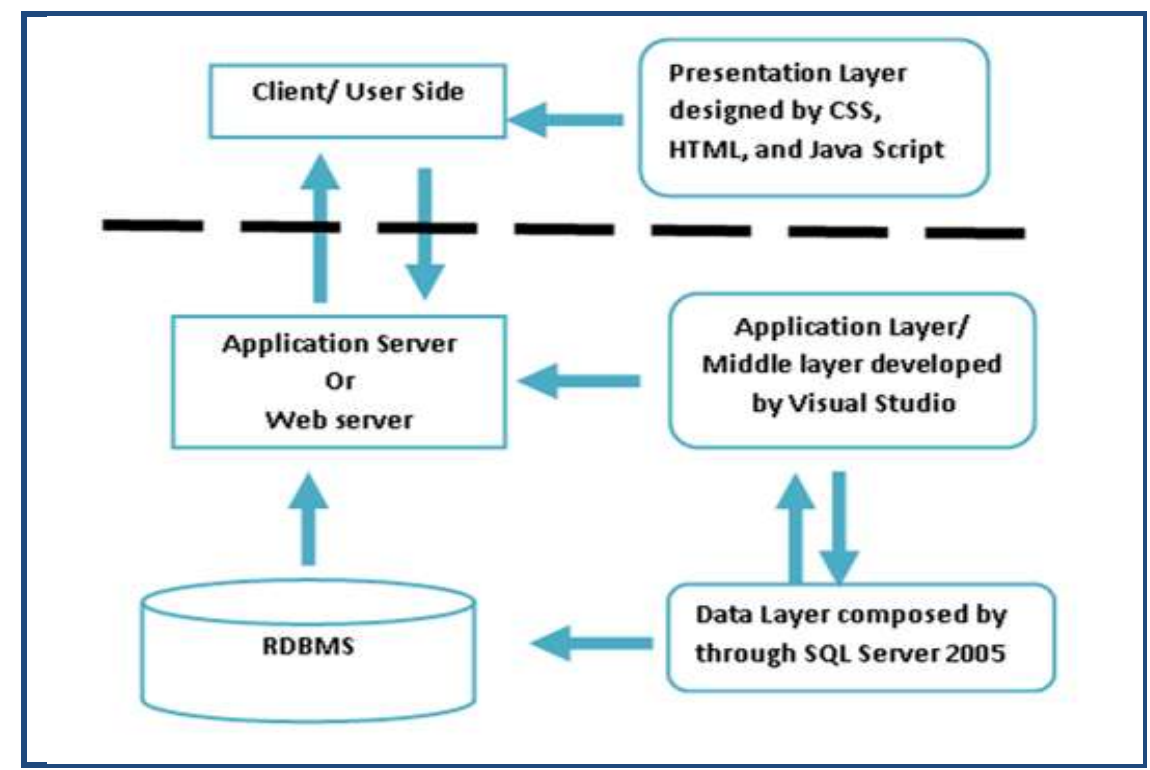

Figure 1: Flow chart of Database Architecture

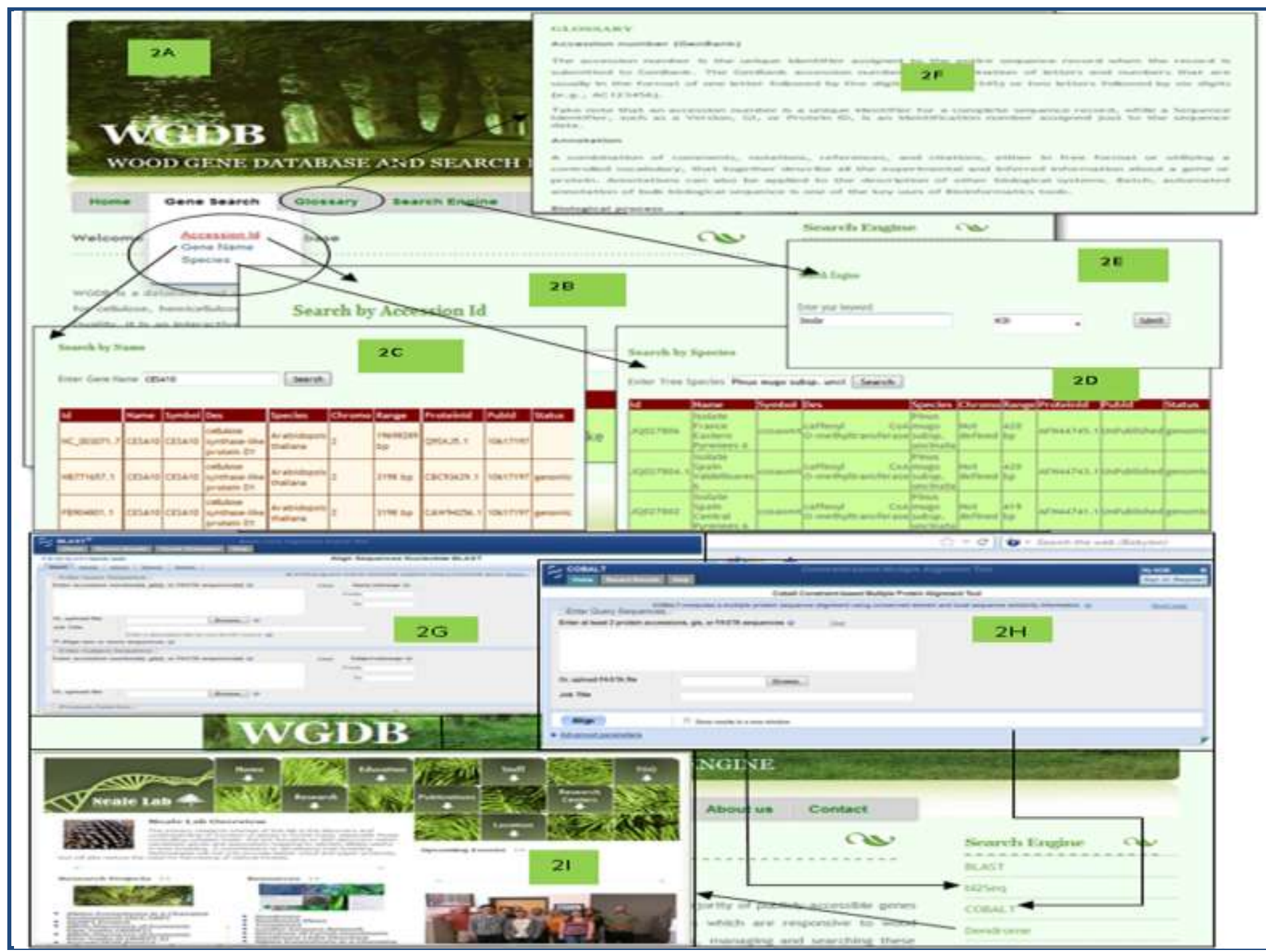

Figure 2: Snapshot of WGDB database: A) Gene search tab; B) Accession id for gene search; C) Search by Gene name; D) Search by species; E) incorporate search engine; F) Glossary tab;. G) BLAST search; H) COBALT: Multiple Sequence Alignment; I) Dendrome project. 


\section{Discussion \& Conclusion:}

WGDB is a user friendly database, which allows the user to input their query text accordingly to the criteria in gene selection namely accession number, gene name or the forest tree species in order to retrieve the related information from the database. Query related hits are displayed in a result page. User can then select any type of query of interest to get the further detailed information. WGDB database have 720 genes entries which are responsible for Cellulose, lignin and hemicelluloses traits in tree species such as pinus [2], poplar [3], deodar [4], Arabidopsis [5].

\section{Database Mining:}

Result page has been connected with different webpage. Home tab explains the information about the wgdb database. Gene Search tab has scroll down menu which has three sub tabs to fulfil the query of user (Figure 2A). These three sub tabs elaborate on different on web pages. User can search wood genes through Accession Id (Figure 2B), by gene name (Figure 2C), by Species name (Figure 2D). User can search wood trait specific genes which are responsible for cellulose [6], lignin \& hemicelluloses. NCBI, EMBL and Google have been incorporated in tab of search engine (Figure 2E) with tab of glossary (Figure 2F). The database has been connected with the bl2Seq (Figure 2G), COBALT (Figure 2H) and Dendrome project (Figure 2I).

\section{Acknowledgement:}

The authors would like to thanks the anonymous reviewers for their valuable comments and Department of Science \& Technology (DST), Government of India for financial support. Forest Research Institute, Dehradun to provide facilities to work.

\section{References:}

[1] Brown GR et al. Genetics. 2003 164: 1537 [PMID: 12930758]

[2] Kovach A et al. BMC Genomics. 2010 11: 420 [PMID: 20609256]

[3] Tuskan GA et al. Science 2006 313: 1596 [PMID: 16973872]

[4] Lin CP et al. Genome Biol Evol. 2010 2: 504 [PMID: 20651328]

[5] Taylor NG et al. Plant Cell. 1999 11: 769 [PMID: 10330464]

[6] Andersson-Gunneras S et al. Plant J. 2006 45: 144 [PMID: 16367961]

Edited by $P$ Kangueane

Citation: Goyal \& Ginwal, Bioinformation 10(1): 039-042 (2014)

License statement: This is an open-access article, which permits unrestricted use, distribution, and reproduction in any medium, for non-commercial purposes, provided the original author and source are credited 


\section{Supplementary material:}

Table 1: Comparison of WGDB with other Wood Databases

\begin{tabular}{|c|c|c|}
\hline Wood Database & About the database & Content of Database \\
\hline WGDB & Wood Gene Database and search engine (www.wgdb.in) & $\begin{array}{l}\text { Gene specific information, i.e responsible for wood } \\
\text { formation/quality }\end{array}$ \\
\hline $\begin{array}{l}\text { Indian Wood } \\
\text { Insect Database }\end{array}$ & $\begin{array}{l}\text { Database of different wood and insects } \\
\text { (http://www.icfre.org: } 8080 / \text { woodsci/) }\end{array}$ & $\begin{array}{l}\text { Comprehensive database of different wood \& } \\
\text { insects that decay the wood. }\end{array}$ \\
\hline $\begin{array}{l}\text { Database of } \\
\text { Japanese wood }\end{array}$ & $\begin{array}{l}\text { Collection } \quad \text { Xylarium } \\
\text { (http://f030091.ffpri.affrc.go.jp/JWDB-E/home.php ) }\end{array}$ & $\begin{array}{l}\text { Collection of limited Xylarium wood images of } \\
\text { Forestry and Forest Product Research Institute, } \\
\text { Japan }\end{array}$ \\
\hline
\end{tabular}

